\title{
KONTRIBUSI METODE MAȘLAHAH MURSALAH IMAM MALIK TERHADAP PENGEMBANGAN HUKUM EKONOMI SYARI'AH KONTEMPORER
}

\author{
Nur Asiyah, Abdul Ghofur \\ Universitas Islam Negeri (UIN) Walisongo Semarang \\ e-mail: nurasiyah2011@gmail.com
}

\begin{abstract}
This paper discusses the contribution of maslahah mursalah Imam Maliki to the development of sharia economic law. Masslahah mursalah is one of the methods of determining Islamic law initiated by Imam Malik. Based on the author's search, there are at least two conclusions about the contribution of the mașlahah mursalah Imam Malik method to the development of shariah economic law. First, mașlahah mursalah as one of the approach model in ijtihād becomes very vital in the development of sharia economic law and siyāsah iqtișādiyyah (economic policy). Because the new problems in the emerging economics in this global world continue to grow, which textually found no proposition in the Qur'an and al-Sunnah. Secondly, the need for fatwas, especially in the fatwa of DSN-MUI, which is based on mașlahah mursalah (kemaslahatan) becomes very urgent. The demands of the times have required the Muslim jurists to see the complexity of the contemporary problem and choose a more convenient (taysir) and avoiding difficulties (al-haraj); And the emergence of new cases requires the existence of ijtihād by considering this mașlahah mursalah aspect.
\end{abstract}

Tulisan ini membahas tentang kontribusi mașlahah mursalah Imam Maliki bagi pengembangan hukum ekonomi syariah. Maslahah mursalah merupakan salah satu metode penetapan hukum Islam yang digagas oleh Imam Malik. Berdasarkan penelusuran penulis, setidaknya ada dua kesimpulan mengenai konstribusi metode mașlahah mursalah Imam Malik terhadap pengembangan hukum ekonomi syari'ah. Pertama, mașlahah mursalah sebagai salah satu model pendekatan dalam ijtihād menjadi sangat vital dalam pengembangan hukum ekonomi syari’ah dan siyāsah iqtisādiyiyah (kebijakan ekonomi). Sebab persoalan baru di bidang ekonomi yang muncul dalam dunia global ini terus berkembang, yang secara tekstual tidak ditemukan dalilnya di dalam al-Qur'an dan alSunnah. Kedua, kebutuhan fatwa, terutama dalam fatwa DSN-MUI, yang didasarkan atas mașlahah mursalah (kemaslahatan ) ini menjadi sangat urgen. Tuntutan perkembangan zaman mengharuskan para ahli hukum Islam melihat kompleksitas masalah kontemporer dan memilih pandangan yang lebih memudahkan (taysir) dan menghindari kesulitan (alharaj); dan munculnya kasus-kasus baru mengharuskan adanya ijtihād mempertimbangkan aspek mașlahah mursalah ini.

Keywords: Imam Malik; mașlaḥah mursalah; hukum ekonomi syari’ah 


\section{Pendahuluan}

Dalam perkembangan hukum Islam, setidaknya ada dua pendekatan yang digunakan oleh para pakar hukum Islam yang berbeda. Pertama, pendekatan nalar (ra'y) dan analogi (qiyās) yang diwakili oleh mazhab Irak. Timbulnya pendekatan dengan menggunakan nalar (ra'y) dan analogi (qiyās) di Irak karena sedikitnya hadis yang beredar di kalangan masyarakat Irak sehingga masyarakat mahir menggunakan nalar ( $r a^{\prime} y$ ) dan analogi (qiyās). Karena kemahirannya dalam menggunakan nalar dan analogi ini mereka disebut ahl alray. ${ }^{1}$ Tokoh utamanya adalah Imam Abu Hanifah. Kedua, pendekatan hadis dan diwakili oleh mazhab Hijaz. Hal ini disebabkan di Hijaz lebih mudah mendapatkan hadis karena di daerah itulah Rasulullah menyampaikan ajarannya, sehingga banyak penghafal hadis. Masyarakat Hijaz mempunyai komitmen yang tinggi terhadap hadis sehingga mereka dikenal dengan ahl al-riwayah ${ }^{2}$ Salah satu tokohnya yang terkenal adalah Imam Malik.

Pemikiran Imam Malik yang dikategorikan sebagai ahl al-hadith, merupakan antitesis dari Mazhab Hanafi yang rasionalis. Ada beberapa alasan yang melatarbelakangi hal ini. Pertama, Imam Malik adalah keturunan Arab yang bermukim di daerah Hijaz. Daerah Hijaz merupakan daerah pusat perbendaharaan hadis Nabi, sehingga setiap masalah yang muncul dengan mudah beliau menjawabnya dengan menggunakan sumber hadis Nabi atau fatwa sahabat. Kedua, semasa hidup beliau tidak pernah meninggalkan tempat tinggalnya dan hanya keluar untuk menunaikan ibadah haji, sehingga beliau tidak pernah bersentuhan dengan kompleksitas budaya. Ketiga, kehidupan ilmiah beliau dimulai dengan menghafal al-Qur'an kemudian menghafal hadis Nabi. ${ }^{3}$

Secara kewilayahan, sebagian besar kelompok ahl al-hadith adalah para ulama yang berada di Madinah. Hal ini disebabkan karena beberapa alasan, antara lain: 1) Madinah adalah tempat tumbuh dan berkembangnya hadis; 2)

\footnotetext{
1Zarkowi Soejoeti, Pengantar Ilmu Fiqh (Semarang: Walisongo Press, 1987), h. 110.

${ }^{2}$ Rasyad Hasan Khalil, Tarikh al-Tasyri' al-Islamy, terj. Nadirsyah Hawari (Jakarta: Amzah, 2009), h. 91-92.

${ }^{3}$ Danu Aris Setiyanto, "Pemikiran Hukum Islam Imam Malik bin Anas: Pendekatan Sejarah Sosial," dalam Al-Ahkam: Jurnal Ilmu Syari'ah dan Hukum, Fakultas Syari'ah IAIN Surakarta, Vol. 1, No. 2,2016, h. 111.
} 
Madinah adalah sebuah kawasan yang dilihat aspek sosio-kulturalnya belum mengalami perkembangan kemajuan yang relatif pesat; 3) Permasalahan yang dihadapi masyarakat Madinah masih relatif sederhana, yang dapat diselesaikan dengan hadis. ${ }^{4}$

Syaikh 'Ali al-Khafif sebagaimana dikutip oleh Dedi Supriyadi menjelaskan hal yang sama yaitu pada zaman tabi'in, dalam pemberian fatwa ada dua aliran yaitu aliran yang bersandar pada penalaran, qiyās, penelitian tentang tujuantujuan hukum dan alasan-alasannya sebagai dasar ijtihād dan aliran yang cenderung bersandar pada bukti-bukti athār (tradisi atau sunnah) dan naș-naș. Aliran yang bersandar pada penalaran dan qiyās ini bertempat di Irak. Hal ini disebabkan Irak mempunyai peradaban sendiri, dinamika kehidupannya lebih kompleks, hadis hanya didapatkan dari sahabat dan tabi'in yang pindah ke Irak sehingga sangat terbatas sehingga keinginan untuk mendapatkan pengetahuan dikaji lewat penalaran. Aliran yang cenderung bersandar pada bukti-bukti athar (tradisi atau sunnah) dan naș-naș bertempat di Hijaz karena Hijaz adalah tempat tinggal Nabi. Di Hijaz Nabi menyampaikan ajarannya dan para sahabat memelihara apa yang disampaikan oleh Nabi dan melaksanakannya. ${ }^{5}$

Imam Malik dikenal sebagai peletak dasar mazhab Maliki yang dikenal sebagai ahli hadis sekaligus ahli fiqih. Pokok-pokok pikiran dan hasil ijtihadnya terutama tertuang dalam kitab al-Muwatța'. Meski telah ditulis kurang lebih 13 abad yang lalu, namun gagasan-gagasannya masih eksis dan banyak diikuti umat Islam di berbagai belahan dunia. Walaupun Imam Malik tidak menulis metode yang digunakan dalam berijtihad, namun dapat diketahui bahwa metode yang ditempuh Imam Malik dalam menetapkan hukum Islam adalah berpegang pada beberapa metode istinbāț al-hukmi, antara lain al-Qur'an, alSunnah, 'amal ahl al-Madīnah (perbuatan penduduk Madinah), mașlahah mursalah atau istișlah, istihsān, sadd al-dharai'.

Dari beberapa metode istinbāt al-ḥukmi yang menarik untuk dikaji adalah mașlaḥah mursalah atau istișlah, sebab, meskipun Imam Malik dikenal sebagai tokoh ahli hadis yang memiliki kecenderungan ke arah tekstualis, namun

\footnotetext{
${ }^{4}$ Dedi Ismatullah, Sejarah Sosial Hukum Islam (Bandung: Pustaka Setia, 2011), h. 335-336.

${ }^{5}$ Dedi Supriyadi, Sejarah Hukum Islam; Dari Kawasan Jazirah Arab Sampai Indonesia (Bandung: Pustaka Setia, 2007), h. 89.
} 
Imam Malik memiliki gagasan istinbāṭ al-hukmi mașlaḥah mursalah yang justru merupakan kecenderungan para tokoh ahli al-ra'yi. Pembahasan mașlahah ini menjadi penting, sebab dapat dikatakan bahwa pondasi bangunan syariat Islam direpresantasikan oleh mașlahah yang ditujukan bagi kepentingan hidup umat manusia sebagai hamba Allah baik menyangkut kehidupan dunianya maupun akhiratnya. ${ }^{6}$ Syariat Islam selalu memperhatikan realisasi mașlaḥah bagi segenap hamba-Nya. Karena itulah, konsep mașlaḥah memberikan kontribusi yang besar dalam mengetahui hukum Allah atas perkara yang tidak ditegaskan oleh naș. Mașlaḥah menjadi elan vital bagi syari'at Islam sehingga ia senantiasa memiliki relevansi dengan konteks zamannya dan pada gilirannya akan menjadikan syariat Islam yang up to date terhadap persoalan kehidupan manusia. ${ }^{7}$ Salah satunya adalah dalam persoalan yang terkait dengan perkembangan ekonomi syari'ah kontemporer.

\section{Pemikiran Fiqh Imam Malik}

\section{Biografi Imam Malik}

Nama lengkap Imam Malik adalah Malik bin Anas bin Malik bin Abi 'Amir bin 'Amr al Ashbahi al-'Araby al-Yamaniyyah. Ibunya bernama 'Aisyah binti Syarik al-Azdiyyah dari kabilah al-Yamaniyyah. ${ }^{8}$ Imam Malik lahir pada tahun $93 \mathrm{H}$ (711 M) di kota Madinah dan wafat pada tahun 179 H (795M) dan dimakamkan di pemakaman Baqi' Madinah. ${ }^{9}$ Imam Malik lahir pada masa Sultan al-Walid bin Abdul Malik dan wafat pada masa Sultan Harun al-Rasyid. ${ }^{10}$

Kakeknya bernama Malik, termasuk salah seorang tabi'in yang banyak meriwayatkan hadis dari 'Umar bin Khattab, 'Utsman bin 'Affan, Thalhah bin 'Ubaidillah dan 'Aisyah Ummul Mukminin. Hadis riwayat Malik ini diriwayat-

${ }^{6}$ Asmawi, "Konseptualisasi Teori Mașlahah" dalam Salam: Jurnal Sosial dan Budaya Syar'i, Fakultas Syari'ah dan Hukum UIN Syarif Hidayatullah Jakarta, Vol. 1, No. 2, 2014, h. 315.

${ }^{7}$ Ibid.

${ }^{8}$ Muhammad Ma'shum Zein, Arus Pemikiran Empat Madzhab; Studi Analisis Istinbath Para Fuqaha (Jombang: Darul Hikmah, 2008), h.140. Dalam buku lain disebutkan bahwa nama ibu Imam Malik adalah Aliyah binti Syuraik dari kabilah Azdi, lihat Rasyad Hasan Khalil, Tarikh al-Tasyri' al-Islamy.., h. 178.

9Yasin Dutton, The Origins of Islamic Law: The Quran, The Muwatta', and Madinan 'Amal, Cet. I (Richmond Survey: Curzon Press, 1999), h. 11.

10Wahbah al-Zuhaily, al-Fiqh al-Islāmy wa Adillatuhu, Juz. 1 (Damaskus: Dar al-Fikr, 1997), h. 45.

62 || Volume 27, Nomor 1, April 2017 
kan oleh anak-anaknya seperti Anas dan Nafi' Abi Suhail, seorang perawi yang menjadi guru Ibnu Syihab al-Zuhri. Dari kehidupan ayah dan kakeknya ini tergambar bahwa kehidupan Imam Malik berada di lingkungan keluarga yang memelihara tradisi keilmuan dan ahli hadis, karenanya ia mencukupkan diri mempelajari ilmu yang tersedia di Madinah. Imam Malik merasa Madinah adalah kota dengan sumber ilmu yang berlimpah lewat kehadiran ulama-ulama besarnya. Perjalanan Imam Malik keluar dari Madinah hanya untuk berhaji. ${ }^{11}$

Imam Malik memulai pendidikannya dengan menghafal al-Qur'an, mencari hadis dan fatwa sahabat, kemudian mendalami ilmu-ilmu keagamaan Islam. Imam Malik mempelajari Qiràah Nafi' Ibn Abi Na'im dan mendengarkan hadis dari ulama-ulama Madinah terkemuka. Di antara gurunya yang paling berpengaruh adalah 'Abd al-Rahman Ibn Hurmuz (w. $118 \mathrm{H}$ ) yang mempunyai laqab al-A'raj. Ia belajar kepada Ibn Hurmuz selama tujuh tahun. Imam Malik juga belajar kepada Nafi' maula Ibn 'Umar (w. 117 H). Setelah banyak memperoleh hadis dari Nafi' kemudian Imam Malik belajar dan mendengarkan hadis dari Ibnu Syihab az Zuhri (w. 124 H). Imam Malik belajar fiqh dari Rabi'ah ibn 'Abd alRahman yang diberi gelar Rabi'ah al-Ra'y (w. 136 H) karena dipandang sebagai ahli fiqh Madinah yang banyak menggunakan ra'y walaupun banyak berbeda pendapat dengan para fuqaha ahl al-ra'y di Irak karena berbeda metode ra'ynya. Ia juga belajar fiqh kepada Yahya ibn Sa'id al-Anshari dari Bani Najjar (w. $143 \mathrm{H}$ ), seorang ahli fiqh yang menjabat qāḍi di Madinah. Setelah lama belajar, Imam Malik mulai membangun majelisnya di masjid Nabawi untuk menyampaikan pelajaran dan fatwa. Ia meriwayatkan hadis dari para gurunya dan dikenal sebagai imam hadis terpercaya. Adapun sanadnya yang paling shahih adalah Malik $\rightarrow$ Nafi' $\rightarrow$ Ibn 'Umar; Malik $\rightarrow$ al-Zuhri $\rightarrow$ Salim $\rightarrow$ Ibn 'Umar; kemudian Malik $\rightarrow$ Abu al-Zinad $\rightarrow$ al-A'raj $\rightarrow$ Abu Hurairah. ${ }^{12}$

Pengembangan pemikiran Imam Malik dilakukan dengan cara, antara lain, pertama mendatangi para ulama di Masjidil Haram, di mana tempat tersebut merupakan tempat dikunjungi para ulama terutama pada musim haji untuk berdiskusi; kedua, mengadakan forum diskusi dengan ulama Madinah. Di sinilah beliau berjumpa dengan Imam Abu Hanifah yang sedang bermukim di Madinah pada saat itu; ketiga, mengembangkan keilmuan keagamaan yang

\footnotetext{
11Zarkowi Soejoeti, Pengantar Ilmu Fiqh, h. 122, Lihat Yasin Dutton, The Origins of Islamic Law.., h. 11-12.

12Zarkowi Soejoeti, Pengantar Ilmu Fiqh, h. 124.
} 
telah dimilikinya melalui bacaan literatur yang sudah ada, baik berupa kitab maupun artikel yang terkait dengan keilmuannya serta mengadakan forum diskusi di kediamannya dengan muridnya dan para ulama yang terkenal pada saat itu seperti Muhammad bin Hasan (murid Abu Hanifah) dan Imam Syafi' i. ${ }^{13}$

Faktor penentu kesuksesan Imam Malik, antara lain ingatan dan hafalan beliau yang sangat kuat. Salah satu contoh kasusnya yaitu pada suatu malam dibacakan 31 hadis oleh gurunya (Ibn Syihab), keesokan harinya beliau sudah lancar menghafalnya tanpa ada yang lupa. Motivasinya dalam menuntut ilmu semata-mata hanya karena Allah. Sikap sabar dan tabah saat mencari ilmu serta pemikirannya yang kritis dan kreatif sehingga mampu memahami persoalan yang ada, baru kemudian melakukan perbandingan. ${ }^{14}$

\section{Karya-karya Imam Malik}

Karya-karya dari Imam Malik diantaranya: al-Muwațta', Kitāb Aq-diyrah, Kitāb Nujum, Hisab Madar al-Zamān, Manāzil al-Qamar, Kitāb Manāsik, Kitāb Tafsìr Li Gharīb al-Qur'ān, Aḥkām al-Qur'ān, al-Mudawanah al-Kubrā, Tafsìr alQur'ān, Kitāb Masa' Islām, Risālah Ibn Ma'rūf Gassan, Risālah ilā al-Lais, Risālah ilā Ibn Wahb. Namun dari beberapa karya-karya tersebut yang sampai pada kita hanya dua yakni al-Muwatta' dan al-Mudawanah al-Kubrā yang berisi fatwa-fatwa dan jawaban Imam Malik atas berbagai persoalan. Al-Muwatța' merupakan kitab pertama yang menghimpun hadis-hadis Nabi karena mayoritas orang-orang sebelum ini mengandalkan hafalan.

Mengenai al-Muwatta', Imam Syafi'i berkata: ${ }^{15}$

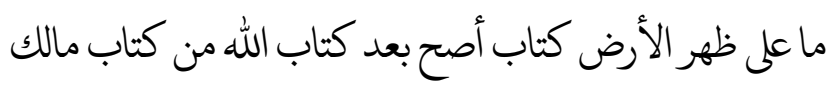

"Tidak ada satu kitab pun di atas permukaan bumi ini yang lebih sahih setelah kitab Allah dari pada kitab Malik."

Karya terbesar Imam Malik ini dinilai memiliki banyak keistimewaan. Ia disusun berdasarkan klasifikasi fiqh dengan memerinci kaidah fiqh yang diambil dari hadis dan fatwa sahabat. Imam Malik menulis kitab ini pada zaman

13Muhammad Ma'shum Zein, Arus Pemikiran EmpatMadzhab., h. 142.

${ }^{14}$ Ibid., h. 143.

15Imam Dar al-Hijrah Malik ibn Anas, al-Muwattá, diriwayatkan oleh Yahya ibn Yahya al-Laitsy (Damaskus: Muassasah Risalah Nasyirun, 2013), h. 10.

$64 \|$ Volume 27, Nomor 1, April 2017 
khalifah Abu Ja'far al-Manshur (754-775 M) dan berhasil disempurnakan pada zaman khalifah al-Mahdi (775-785 M). Khalifah Harun al-Rasyid pernah mencoba menjadikan kitab ini sebagai undang-undang resmi kehakiman negara, tetapi Imam Malik idak berkenan karena tidak ingin mempersulit masyarakat umum dalam memutuskan urusan mereka. ${ }^{16}$

\section{Mazhab Maliki dan Perkembangannya}

Metode pengajaran Imam Malik didasarkan pada ungkapan hadis dan pembahasan atas makna-maknanya kemudian dikaitkan dengan konteks permasalahan yang ada pada masa itu. Imam Malik juga meriwayatkan kepada murid-muridnya berbagai hadis dan atsar (pernyataan para sahabat) atas berbagai topik hukum Islam dan kemudian mendiskusikan implikasi-implikasinya. Kadangkala Imam Malik meneliti di tempat murid-muridnya berasal, kemudian mencarikan hadis-hadis atau atsar-atsar yang bisa digunakan untuk memecahkan masalah tersebut.

Setelah selesai menyusun al-Muwattá, Imam Malik menjelaskan kitab tersebut kepada murid-muridnya sebagai mazhabnya. Imam Malik akan selalu menambahkan di dalamnya ketika ada informasi-informasi baru yang sampai kepadanya. Imam Malik sangat menghindari spekulasi dan fiqh hipotesis, sehingga mazhab dan pengikutnya disebut ahl al-hadith. ${ }^{17}$

Perkembangan mazhab Maliki tidak bisa lepas dari jasa para murid yang telah meriwayatkan dan menyebarkan mazhabnya setelah Imam Malik wafat. Mereka berhasil memperluas pembahasan, manhaj dan perinciannya. Mazhab Maliki tersebar di negeri Hijaz karena di situlah ia lahir dan berkembang, juga tersebar di Mesir, Tunisia, Aljazair dan Maroko, Torablus dan Sudan dan dominan di Bashrah dan Baghdad. Kitab al-Muwatta' merupakan salah satu faktor utama bagi tersebarnya mazhab Maliki. ${ }^{18}$

Murid-murid Imam Malik antara lain:19 dari kelompok Mesir adalah Abu Abdullah, Abdurrahman bin Qasim (w. 191 H), ${ }^{20}$ Abu Muhammad, Abdullah bin

\footnotetext{
16Rasyad Hasan Khalil, Tarikh al-Tasyri' al-Islamy.., h. 184.

${ }^{17}$ Abu Ameenah Bilal Phipips, The Evolution of Fiqh Islamic Law and The Madh-habs, Cet. II (Kuala Lumpur: A.S. Noordeen, 1411H./1990M), h. 78-79.

18Rasyad Hasan Khalil, Tarikh al-Tasyri' al-Islamy.., h. 184.

${ }^{19}$ Wahbah al-Zuhaily, al-Fiqh al-Islāmy wa Adillatuhu, h. 46-49.
} 
Wahb bin Muslim (w. 197 H),21 'Asyhab bin Abdul Aziz al-Qaisy (w. 204), Abu Muhammad, Abdullah bin Abdul Hakam (w. 214 H), Ashbagh bin Faraj (w. 225 H), Muhammad bin Abdullah bin Abdul Hakam (w. 268 H), Muhammad bin Ibrahim al-Iskandary bin Ziyad yang dikenal dengan Ibnu Muwwaz (w. 269 H).

Dan dari kelompok Maghrib (barat) adalah Abul Hasan, 'Ali bin Ziyad AlTunisy (w. 183 H), Abu Abdillah, Ziyad bin Abdirrahman al-Qurthuby (w. 193 H), 'Isa bin Dinar, al-Qurthuby al-Andalusy (w. 212 H), Asad bin Farat bin Sinan al-Tunisy (w. 213 H), Yahya bin Yahya bin Katsit al-Laitsy (w. 234 H), Abdul Malik bin Habib bin Sulaiman al-Sulamy (w. 238 H), Sahnun, Abdul al-Salam bin Said al-Tanukhy (w. $240 \mathrm{H}$ ).

Murid-muridnya yang ada di Hijaz dan Irak adalah Abu Marwan, Abdul Malik bin Abi Salamah al-Majisyun (w. 212 H), Ahmad bin Mu'adzdzal bin Ghailan al-'Abdy, Abu Ishaq, Ismail bin Ishaq al-Qadhy (w. 282 H). Murid Imam malik yang terkenal lainnya, yang nantinya menjadi tokoh mazhab tersendiri adalah Muhammad Ibn Idris al-Syafi'i atau dikenal dengan Imam al-Syafi'i (150-204 H).

\section{Faktor-faktor yang Mempengaruhi Pola Pemikiran Imam Malik dalam Penetapan Hukum Islam}

\section{Pola Pemikiran Imam Malik dalam Menetapkan Hukum Islam}

Imam Malik merupakan ulama yang sangat teguh dalam membela kebenaran dan berani menyampaikan apa yang menjadi keyakinannya tentang kebenaran tersebut. Pada tahun 764 M, misalnya, Imam Malik ditangkap dan dianiaya atas perintah Amir Madinah, karena mengeluarkan ketetapan hukum bahwa perceraian yang dipaksa adalah tidak sah. Ketetapan ini bertentangan dengan praktik para penguasa Abbasiyah mengenai tambahan kalimat sumpah setia dalam perkawinan pada mereka yang disaksikan orang banyak de-

${ }^{20} \mathrm{Al}-\mathrm{Q} a s i m$ lahir di Mesir, ia pindah ke Madinah, tempat ia belajar pada gurunya yaitu Imam Malik, selama dua puluh tahun. Imam al-Qasim menulis buku tentang fiqh madzhab Maliki yang berjudul $a l-$ Mudawwanah. Lihat Wahbah al-Zuhaily, al-Fiqh al-Islāmy wa Adillatuhu, h. 46 dan Abu Ameenah Bilal Phipips, The Evolution of Fiqh.., h. 81.

21Ibnu Wahab berasal dari Mesir dan ke Madinah untuk belajar pada Imam Malik. Ibnu Wahab memiliki keahlian mendeduksi hukum. Ibnu Wahab dijuluki al-Mufty oleh Imam Malik, lihat Abu Ameenah Bilal Phipips, The Evolution of Fiqh.., h. 81. 
ngan kata-kata bahwa siapapun yang melanggar sumpah tersebut maka secara otomatis mereka terceraikan. Imam Malik diikat dan dipukul sampai lengannya sakit dan tidak mampu bersedekap ketika shalat sehingga Imam Malik melakukan shalat dengan tangan di sisinya. ${ }^{22}$

Dalam bidang hadis, kepiawaian Imam Malik tidak diragukan lagi, sebagaimana yang dikatakan Ma'shum Zein yang mengutip Imam Syafi'i: 'Apabila datang kepadamu al-hadith dari Imam Malik, maka pegang teguhlah olehmu, karena ia menjadi hujjah bagimu' dan Imam al-Dahlawi: Imam Malik adalah seorang ilmuwan Madinah yang ahli dalam bidang hadis, sebab beliau adalah ilmuwan yang paling mengetahui tentang keputusan-keputusan 'Abdullah Ibn 'Umar dan 'Aisyah serta sahabat-sahabat mereka. Dalam masalah hukum dan fatwa, Imam Malik menyatakan tidak pernah memberikan fatwa dan meriwayatkan suatu hadis sebelum 70 ulama membenarkan dan mengakui kebenaran akan fatwanya. ${ }^{23}$

\section{Faktor-faktor yang Mempengaruhi Imam Malik dalam Penetapan Hukum Islam}

Malik bin Anas adalah Imam ahl al-Madīnah dan amìr al-mu'minīn fi 'lhadith, yang dilahirkan di Madinah dan tidak pernah pergi meninggalkan kota kecuali ke Makkah untuk menunaikan ibadah haji. Karena hal itulah amalanamalan penduduk Madinah ${ }^{24}$ sangat mempengaruhinya. Bahkan, khabar ahad dapat diterima oleh beliau sebagai salah satu dasar pengambilan hukum selama tidak bertentangan dengan amalan-amalan ahl al-Madinah atau dikuatkan oleh dalil lain yang qațí.

\footnotetext{
${ }^{22} \mathrm{Abu}$ Ameenah Bilal Phipips, The Evolution of Fiqh.., h. 78.

${ }^{23}$ Muhammad Ma'shum Zein, Arus Pemikiran Empat Madzhab.., h. 145.

${ }^{24}$ Setelah hijrah, Rasulullah bersama-sama para sahabatnya bertempat tinggal di kota Madinah. Sepeninggal Rasulullah, Madinah merupakan tempat al-hadist yang paling banyak, karena realitas sejarahnya banyak para sahabat yang menetap di Madinah. Kota Madinah juga telah melahirkan beberapa tabi' in yang ahli dan memiliki peran dalam pengembangan hadis, diantaranya adalah Sa'id bin Musayyab, Urwah bin Zubair, Ibnu Syihab al-Zuhri, Ubaidillah bin Utbah bin Mas'ud, Salim bin Abdullah bin Umar, Muhammad bin al-Munkadir dan masih banyak yang lain. Oleh sebab, kota Madinah jika dibandingkan dengan kota-kota lain dalam dunia Islam, masih tetap merupakan kota yang paling banyak perbendaharaan sunnah, sehingga kota Madinah dikenal sebagai 'Dār al-Sunnah'. Lihat Muhammad Ma'shum Zein, Arus Pemikiran Empat Madzhab.., h. 151.
} 
Imam Malik dikenal sebagai ulama yang beraliran ahl al-hadith. Meskipun demikian, tidak berarti bahwa Imam Malik menolak secara mutlak terhadap al-ra'yu, sebab beliau tetap menggunakan metode al-mașlahah al-mursalah dan istihsān sebagai dasar pengambilan hukumnya. Padahal kedua metode ini merupakan basis pengembangan hukum Islam yang dipegangi oleh kalangan ahl al-ra'yu.

Kuatnya Imam Malik terhadap apa yang menjadi tradisi oleh penduduk Madinah dalam hal keagamaan merupakan upaya untuk merujuk pada generasi sebelumnya yang 'diduga kuat' berpangkal pada amalan-amalan yang bersumber pada pribadi Rasulullah. Dengan demikian Imam Malik sangat memegangi bahwa 'amal ahl al-Madīnah sebagai salah satu dasar pondasi pengambilan hukum Islam. Akan tetapi, Imam Malik tidak mewajibkan orang-orang dari kota atau negara lain untuk mengikuti 'amal ahl al-Madīnah, karena hal ini hanya merupakan salah satu pilihan saja. ${ }^{25}$

\section{Metode Mașlahah Mursalah Imam Malik dalam Penetapan Hukum Islam}

Imam Malik beserta pengikutnya menjadikan mașlaḥah mursalah sebagai salah satu dalil hukum dan hujjah dalam menetapkan hukum. ${ }^{26}$ Imam Malik dan pengikutnya merupakan mazhab pencetus dan menyuarakan mașlaḥah mursalah sebagai dalil hukum dan hujjah syari'ah. ${ }^{27}$ Kecenderungan yang kuat dalam penggunaan metode mașlahah mursalah ini pada awalnya merupakan khas pemikiran Imam Malik yang diduga kuat merupakan pengaruh dari pemikiran tokoh fikih para sahabat, seperti Umar bin Khaththab.

Metode ini kemudian mendapat legitimasi dari semua mazhab sesudahnya meskipun dengan sebutan yang berbeda. Dalam teori ini dapat diketahui bahwa Imam Malik di satu sisi sangat kuat dan populer dengan penggunaan hadis, di sisi lain, ia juga tetap menggunakan rasio.28 Menurut Imam Malik, hukum

\footnotetext{
25Muhammad Ma'shum Zein, Arus Pemikiran Empat Madzhab.., h. 152.

26Ramli, SA, Muqaranah Madhāhib fi 'I-Ușūl (Jakarta: Gaya Media Pratama, 1999),h. 168.

27Muhammad Abu Zahrah, Ușūl al-Fiqh (Mesir: Dar al-'Arabi, 1958), h. 280.

${ }^{28}$ Danu Aris Setiyanto, "Pemikiran Hukum Islam Imam Malik Bin Anas (Pendekatan Sejarah Sosial)" dalam Al-Ahkam: Jurnal Ilmu Syari'ah dan Hukum, Fakultas Syari'ah IAIN Surakarta, Vol. 1 No. 2 Tahun 2016, h. 110.
} 
syari'ah (al-ḥukm al-sharí) bisa ditunjukkan oleh dalil atau sesuatu yang dikandung oleh dalil (al-mutadaman li '1-dalīi). Dalil bisa berupa al-kitab (alQur'an), al-Sunnah, al-istişhāb dan al-qiyās. Sedangkan al-mutaḍaman li ' l-dalīl bisa berupa ijmā', qawl al-șahabi, maṣlahah mursalah, al-istihsān, al-urf dan sadd al-dhara 'i'. Metode ini dikenal dengan istilah istidlāl.29

Secara etimologi, mașlahah adalah perbuatan yang mendorong pada kemanfaatan manusia, merupakan lawan kata dari mafsadat. Mașlaḥah dengan makna yang umum adalah segala sesuatu yang di dalamnya terdapat kemanfaatan baik dengan cara menarik atau menghasilkan. ${ }^{30}$ Secara terminologi, mașlahah mursalah adalah suatu kemashlahatan dimana syari' tidak mensyariatkan suatu hukum untuk merealisir kemashlahatan itu, dan tidak ada dalil yang menunjukkan atas pengakuannya atau pembatalannya. ${ }^{31}$ Mașlaḥah mursalah pada prinsipnya adalah menetapkan hukum berdasarkan kemaslahatan yang ketentuan hukumnya tidak terdapat dalam naș, baik al-Qur'an maupun al-Sunnah.

Al-Syatibi, salah satu Ulama' Mazhab Maliki mengatakan bahwa mașlaḥah mursalah adalah setiap prinsip syara' yang tidak disertai naș khusus, namun sesuai dengan tindakan syara' serta maknanya diambil dari dalil-dali syara'. Makna prinsip tersebut adalah sah sebagai dasar hukum dan dapat dijadikan bahan rujukan sepanjang ia telah menjadi prinsip dan digunakan oleh syara' yang qaț'y. Mașlahahah mursalah terbagi menjadi tiga. yaitu: d̦arūriyyah, hajüyyah dan tahsiniyyah. ${ }^{32}$

Kemaslahatan manusia (mașlaḥah) dalam kehidupan ini pada dasarnya sangat banyak dan beraneka ragam. Sebagian memang benar-benar untuk kebaikan manusia, namun sebagian yang lain hanya sangkaan saja untuk kebaikan manusia. Dalam hal ini mașlaḥah terdiri dari tiga macam: mașlaḥah mu'tabarah (mașlaḥah yang sesuai dengan syariat), mașlahah mulghah (maș-

${ }^{29}$ Muhammad Abdul Ghani al-Bajqani, al-Madkhal ilā Ușūl al-Fiqh al-Maliki (Beirut: Dar Libnan li al-Tiba'ah wa al-Nasyr), h. 9.

30Jalaluddin Abdurrahman, al-Mașālị al-Mursalah wa Makānatuhā fi al-Tashri' (Mathba'ah alSa'adah, 1983), h. 12.

${ }^{31}$ Abdul Wahab Khalaf, Ilmu Ushul al-Fiqh, terjemahan Muh Zuhri dan Ahmad Qorib (Semarang: Toha Putra, 1994), h. 116.

${ }^{32} \mathrm{Abi}$ Ishaq al-Syatibi, al-Muwafaqat fi Ușūl al-Sharīah (Beirut: Dar al-Ma'rifat, 2004), h. 324. 
laḥah yang bertentangan dengan syariat), dan mașlaḥah mursalah (mașlaḥah yang tidak ditentukan dan tidak dilarang oleh syariat). ${ }^{33}$ Mașlahah yang dapat diterima adalah mașlahah yang bersifat hakiki, yaitu meliputi lima jaminan dasar, yaitu: keselamatan keyakinan agama; keselamatan jiwa; keselamatan akal; keselamatan keluarga dan keturunan serta keselamatan harta benda. Kelima jaminan dasar itu merupakan tiang penyangga kehidupan dunia agar manusia dapat hidup aman dan sejahtera. ${ }^{34}$

Menurut Imam Malik, mașlahah murslahah ini dapat dijadikan hujjah dalam penggalian hukum Islam. Menurut Imam Malik, mașlahah dapat diambil dari naș atau dari keumuman apa yang terdapat dalam naș. Mașlaḥah mursahah ini adalah mașlahah yang tidak ada perintah atau larangan dari Allah, namun di dalam terdapat manfaat yang lebih banyak daripada kemudaratannya yang bertujuan untuk kemaslahatan manusia pada umumnya dan menjauhi kemafsadatan (kerusakan). ${ }^{35}$

Mașlahah mursalah merupakan salah satu asas perumusan pendapat hukum dari Imam Malik yaitu menarik manfaat dan menghindari madarat yang tidak diakui tetapi juga tidak diingkari secara eksplisit dalam syara'. Penetapan ini bertolak dari kesimpulan bahwa perintah dan larangan dibebankan pada manusia merujuk pada maksud-maksud syara', ${ }^{36}$

Imam Malik menjadikan mașlaḥah mursalah sebagai dalil hukum dan hujjah dalam menetapkan hukum. Imam Malik mengajukan tiga syarat dalam menggunakan mașlahah mursalah yaitu: Pertama, adanya persesuaian antara mașlahah yang dipandang sebagai sumber dalil yang berdiri sendiri dengan tujuan-tujuan syariat (maqāșid al-sharīah). Dengan adanya persyaratan ini, berarti mașlahah tidak boleh menegasikan sumber dalil yang lain atau bertentangan dengan dalil yang qațiy; Kedua, mașlahah harus masuk akal (rasionable), mempunyai sifat-sifat yang sesuai dengan pemikiran yang rasional, dimana seandainya diajukan kepada kelompok rasionalis akan dapat diterima; Ketiga, penggunaan dalil mașlahah ini adalah dalam rangka meng-

\footnotetext{
33Jalaluddin Abdurrahman, al-Mașālih al-Mursalah wa Makānatuhā fi al-Tashrī', h. 18.

${ }^{34}$ Wahbah al-Zuhaily, Ușūl Fiqh al-Islämy (Beirut: Dar al-Fikr, 2004), h. 752.

${ }^{35}$ Ibid., h. 759.

${ }^{36}$ Zarkowi Soejoeti, Pengantar Ilmu Fiqh, h. 126.
} 
hilangkan kesulitan yang mesti terjadi (raf'u haraj lazim). Dalam pengertian, seandainya mașlahah yang dapat diterima akal itu tidak diambil, niscaya manusia akan mengalami kesulitan. ${ }^{37} \mathrm{Hal}$ ini sesuai dengan QS. al-Hajj ayat 78.

Dalam pandangan Mazhab Maliki yang dikenal sebagai pembawa bendera mașlahah mursalah mengemukakan tiga argumentasi yang mendasari kehujjahan metode istinbāt ini yaitu: Pertama, praktek para sahabat yang telah menggunakan mașlahah mursalah seperti penghimpunan mushaf al-Qur'an. Penghimpunan ini dilakukan karena khawatir al-Qur'an bisa hilang. Pengumpulan al-Qur'an dalam satu mushaf ini, semata-mata demi kemaslahatan. Contoh lainnya adalah perintah Umar bin Khattab kepada para penguasa agar memisahkan antara harta kekayaan pribadi dengan harta yang diperoleh dari kekuasaannya. Hal ini dimaksudkan agar penguasa dapat menunaikan tugasnya dengan baik dan tercegah dari manipulasi dan korupsi; Kedua, keberadaan mașlaḥah mursalah ini sesuai dengan maqāșid al-sharīah yang berarti bahwa dengan mengambil mașlaḥah berarti sama dengan merealisasikan maqāṣid alsharīah. Sebaliknya mengesampingkan mașlaḥah berarti mengesampingkan maqāșid al-sharīah; Ketiga, seandainya mașlaḥah tidak diambil pada setiap kasus yang jelas mengandung mașlahah selama berada dalam konteks mașlahah shar'iyyah maka orang mukallaf akan mengalami kesulitan dan kesempitan. Hal ini sesuai dengan QS. al-Hajj ayat 76 dan QS. al-Baqarah ayat 185.38

Menurut Imam Malik, mașlaḥah mursalah adalah kemaslahatan yang tidak ada pembatalannya dari naș dan juga tidak disebutkan secara jelas oleh naș akan tetapi mașlaḥah mursalah ini tidak boleh bertentangan dengan naș sebagai sumber pokok. Teori mașlahah mursalah menurut Imam Malik sebagaimana dinukilkan oleh Imam Syatibi dalam kitab al-I'tișām adalah suatu maslahat yang sesuai dengan tujuan, prinsip, dan dalil-dalil syara', yang berfungsi untuk menghilangkan kesempitan, baik yang bersifat darūriyyah (primer) maupun hajjïyyah (sekunder). ${ }^{39}$

\footnotetext{
${ }^{37}$ Muhammad Abu Zahrah, Ușūl al-Fiqh (Beirut: Dar al-Fikr al-Araby, 1958), h. 279-280.

${ }^{38}$ Ibid., h. 282.

${ }^{39} \mathrm{Abu}$ Ishaq al-Syatibi, al-I'tișām, Jilid II (Beirut: Dar al-Ma'rifah, 1975), h. 39.
} 
Selain menggunakan mașlaḥah mursalah tersebut, Imam Malik juga mendasarkan pada al-Qur'an, al-Sunnah,40 qiyās, istihsā̄n, ijmā' ahl al-Madīnah,41 fatwa șahabat,"42 istiṣhāb, sadd al-dhara'i, al-'urf, shar'u man qablanā. Dengan metode-metode inilah Imam mengembangkan hukum Islam dan menyebar ke berbagai penjuru dunia.

\section{Kontribusi Mașlaḥah Mursalah terhadap Pengembangan Ekonomi Syari'ah Kontemporer}

\section{Maṣlaḥah sebagai Tujuan Antara untuk Menggapai Falāḥ (Kebahagiaan)}

Salah satu metode istinbāt hukum yang dikembangkan oleh Imam Malik dan memiliki konstribusi terhadap pengembangan hukum Islam adalah metode istișlah atau mașlahah mursalah atau ringkasnya mașlahah. Penempatan mașlahah sebagai prinsip utama dalam ekonomi Islam ini memiliki peran yang cukup strategis. Dapat dikatakan bahwa dalam studi prinsip ekonomi Islam, mașlahah. Mașlahah adalah tujuan syari'ah Islam dan menjadi inti utama syari'ah Islam itu sendiri. Dengan demikian, sangat tepat dan proporsional apabila mașlahah ditempatkan sebagai prinsip kedua dalam ekonomi Islam. Oleh karena itu prinsip mașlahah dalam bidang muamalah menjadi acuan dan patokan penting.

\footnotetext{
40Fazlur Rahman melihat pengertian sunnah dalam kitab Muwattța' Imam Malik dengan menganalisa hadis yang dikutip Imam Malik. Penjelasan Rahman menunjukan bahwa sejak awal imam Malik sudah membedakan antara sunnah dalam pengertian literal dan sunnah dalam pengertian teladan dari Nabi. Lihat Fazlur Rahman, Membuka Pintu Ijtihad, terjemahan Anas Mahyuddin (Bandung: Pustaka, 1984), h. 18-20. Lihat juga dalam Juandi, "Aspek Sosio-Politik dalam Konstruksi Hukum Imam Malik bin Anas", dalam Jurnal Istinbath, Vol. 9, No. 1, 2012, h. 1-19

${ }^{41}$ Ijma' ahl al-Madīnah ini terdiri dari dua macam; pertama, ijma' dengan cara mendasarkan pada dalil naqli yang mutawatir, baik berupa perkataan, tindakan, taqrir atau meninggalkan sesuatu, kedua, ijma'yang didasarkan cara berijtihad. Macam yang pertama, menurut ulama Malikiyyah dapat dijadikan hujjah yang bersifat qath'i dan wajib dijalankan. Sedangkan macam yang kedua, yakni dengan cara ijtihad, menurut fuqaha' dapat dipertimbangkan sebagai hujjah. Lihat Muhammad Abdul Ghani al-Bajqani, al-Madkhal ilā Ușūl al-Fiqh al-Maliki, h. 132.

42Menurut Ibnul Qayyim dikutip al-Bajqani dan Abu Zahrah, fatwa sahabat tidak keluar dari enam hal, yaitu: fatwa itu didengar langsung dari Rasulullah; fatwa itu didengar dari sahabat yang mendengarkan fatwa Rasulullah; fatwa itu dipahami dari ayat suci al-Qur’an; fatwa itu sudah disepakati, tetapi hanya disampaikan seorajng mufti; fatwa itu berupa pendapat sahabat pribadi; fatwa itu berasal dari pemahaman pribadi sahabat, bukan dari Rasulullah dan apabila pemahaman itu salah, maka tidak dapat dijadikan hujjah. Muhammad Abdul Ghoni al-Bajqani, al-Madkhal ilā Ușūl al-Fiqh al-Maliki, h. 132-133, Lihat. Muhammad Abu Zahrah, Ușūl al-Fiqh, h.331-332.
} 
Apalagi bila menyangkut kebijakan-kebijakan ekonomi yang dikategorikan sebagai manțiqah al-firagh al-tashrīy (area yang kosong dari tasyri' / hukum). ${ }^{43}$

Masalah ekonomi hanyalah merupakan satu bagian dari aspek kehidupan yang diharapkan akan membawa manusia kepada falāh (kesuksesan, kemuliaan, kemenangan, kebahagiaan) sebagai tujuan hidupnya. Istilah falāh menurut Islam diambil dari kata-kata al-Qur'an yang sering dimaknai sebagai keberuntungan jangka panjang, dunia dan akhirat. Dalam konteks dunia, falāh merupakan konsep yang multi dimensi. Untuk kehidupan dunia, falăh mencakup tiga pengertian, yaitu; kelangsungan, kebahagiaan hidup serta kekuatan dan kehormatan. Ia memiliki implikasi pada aspek perilaku individual/mikro maupun perilaku kolektif/makro. Sedangkan untuk kehidupan akhirat, falāh mencakup pengertian kelangsungan hidup yang abadi, kesejahteraan abadi, kemuliaan abadi dan pengetahuan abadi. ${ }^{44}$ Kehidupan yang mulia dan sejahtera di dunia dan di akhirat (falāh) dapat terwujud apabila terpenuhi kebutuhan-kebutuhan hidup manusia secara seimbang. Terpenuhinya kebutuhan masyarakat akan memberikan dampak mașlaḥah.

Sedikitnya naș-naș yang menyinggung masalah yang terkait dengan kebijakan-kebijakan ekonomi teknis, membuka peluang yang besar untuk mengembangkan ijtihād dengan prinsip mașlaḥah. Al-mașlaḥah sebagai salah satu model pendekatan dalam ijtihād menjadi sangat vital dalam pengembangan ekonomi Islam dan siyāsah iqtișādiyiah (kebijakan ekonomi). Mașlaḥah adalah tujuan yang ingin diwujudkan oleh syariat. Al-Mașlahah merupakan esensi dari kebijakan-kebijakan syariah (siyasah syarïyyah) dalam merespons dinamika sosial, politik, dan ekonomi. Mașlahah 'āmmah (kemaslahatan umum) merupakan landasan muamalah, yaitu kemaslahatan yang dibingkai secara syar'i, bukan semata-mata profit motive dan material rentability sebagaimana dalam ekonomi konvensional. 45

Semakin banyaknya persoalan baru yang muncul dalam dunia global ini, yang secara tekstual tidak ditemukan dalilnya di dalam al-Qur'an dan al-

\footnotetext{
43Sakirman, "Urgensi Mașlahah dalam Konsep Ekonomi Syari’ah" dalam PALITA: Journal of SocialReligi Research April 2016, Vol.1, No.1, h.17-28.

${ }^{44}$ M. Nadratuzzaman Hosen dkk, Materi Dakwah Ekonomi Syari'ah (Jakarta: Pusat Komunikasi Ekonomi Syari'ah/PKES), h. 2-3.

${ }^{45}$ Agustianto, "Urgensi Maṣlaḥah dalam Ijtihad Ekonomi Islam" dalam http://www. agustiantocentre.com/?p=424 diunduh pada hari Selasa, 28 Maret 2017.
} 
Sunnah., ijma' dan qiyās, bahkan dalam kitab-kitab fiqh yang ditulis para fuqaha pada masa lalu, membuat ahli hukum Islam masa kini melakukan ijtihād. salah satu metode ijtihād yang banyak dipergunakan para ahli hukum Islam kontemporer untuk menemukan hukum Islam adalah al-Mașlahah atau mașlahah mursalah. Dalam pandangan ekonomi syari'ah, tujuan hidup manusia yang utama adalah mencapai kebahagiaan (falāh). Untuk kehidupan dunia, falăh mencakup tiga pengertian yaitu kelangsungan hidup, kebebasan berkeinginan, serta kekuatan dan kehormatan. Sedangkan untuk kehidupan akhirat, falāh mencakup pengertian kelangsungan hidup yang abadi, kesejahteraan yang abadi, kemuliaan abadi, dan pengetahuan abadi. ${ }^{46}$ Falāh dapat terwujud apabila terpenuhi kebutuhan-kebutuhan hidup manusia secara seimbang. Tercukupinya kebutuhan masyarakat akan memberikan dampak yang disebut dengan mașlahah. ${ }^{47}$ Mașlaḥah adalah segala keadaan, baik material maupun non-material yang mampu meningkatkan kedudukan manusia sebagai makhluk yang paling mulia.

Penerapan mașlạ̣ah dalam ekonomi Islam (mu'ämalah) memiliki ruang lingkup yang lebih luas dibanding ibadah. Ajaran Islam tentang muamalah umumnya bersifat global, karena itu ruang ijtihād untuk bergerak lebih luas. Ekonomi Islam yang menjadi salah satu bidang muamalah berbeda dengan ibadah murni ('ibādah maḥ̣ah). Ruang ijtihād dalam bidang ibadah sangat sempit. Hal ini berbeda dengan bidang muamalah termasuk di dalamnya adalah ekonomi Islam, yang cukup terbuka bagi inovasi dan kreasi baru dalam membangun dan mengembangkan ekonomi Islam dengan berlandaskan pada kemaslahatan (mașlahah). ${ }^{48}$ Bahkan dapat dikatakan bahwa prinsip utama dalam formulasi ekonomi Islam dan perumusan fatwa-fatwa serta produk keuangan adalah mașlahah. Kehadiran lembaga-lembaga perbankan dan keuangan syari'ah, Inovasi zakat produktif dan waqaf tunai juga didasarkan kepada mașlahah. Pendeknya semua aktivitas dan perilaku dalam perekonomian acuannya adalah mașlaḥah. Jika di dalamnya ada kemaslahatan, maka

\footnotetext{
46Pusat Pengkajian dan Pengembangan Ekonomi Islam (P3EI), Ekonomi Islam (Jakarta: Rajawali Pers, 2012), h. 2.

${ }^{47}$ Mașlaḥah sering dinyatakan dengan manfaat atau manafi' (QS. 6:76; 14:5; 17:28; 18;21; 27:55) juga dengan istilah hikmah, barakah (QS. 2:269; 24:41) yang berarti imbalan baik yang dijanjikan Allah di dunia maupun di akhirat.

48Said Abdullah Syahab, "Al-Mașlaḥah dan Ijtihad dalam Ekonomi Islam" dalam Jurnal TAJDID Vol. XII, No. 2, Juli-Desember 2013, h. 736
} 
hal itu dibenarkan dan dianjurkan oleh syari'ah. Sebaliknya jika di sana ada kemudratan dan mafsadah, maka prakteknya tidak dibenarkan, seperti ribā, maysir, gharār, ihtikar dan lain-lain.

\section{Mașlaḥah sebagai Fondasi Pengembangan Hukum Ekonomi Syari'ah melalui Fatwa Ulama di Indonesia}

Selama ini, lembaga yang merepresentasikan ormas Islam di Indonesia dan diberi kewenangan untuk mengeluarkan fatwa adalah Majelis Ulama Indonesia (MUI). Penetapan fatwa ekonomi syari'ah juga diamanahkan kepada MUI. Untuk menangani hal ini, MUI membentuk Dewan Syari'ah Nasional Majelis Ulama Indonesia (DSN-MUI) yang khusus menjalankan fungsi MUI dalam bidang ekonomi syari'ah, yang meliputi penetapan fatwa ekonomi syari'ah, pemberian opini syari'ah produk lembaga keuangan syari'ah ataupun regulator, pengawasan kesesuaian syari'ah di setiap LKS, dan pemberian rekomendasi Dewan Pengawas Syari'ah (DPS).

Dalam merespons permasalahan ekonomi syaiah yang berkembang, DSNMUI melakukan ijtihād jamā'i yang dalam proses penetapannya menggunakan tiga pendekatan, yaitu pendekatan naș qaț'y, pendekatan qawly dan pendekatan manhajy. Pendekatan naș qaț'y dilakukan untuk menetapkan suatu masalah yang sudah terdapat dalam nas al-Qur'an dan al-Sunnah secara jelas. Pendekatan qawly dilakukan apabila permasalahan yang ada ditemukan jawabannya melalui pendapat ahli fiqh yang terdapat dalam al-kutub almu'tabarah yang illah hukumnya sesuai dengan yang terjadi saat ini. Apabila jawaban yang dimintakan fatwa tidak terdapat dalam nas qaț'y dan al-kutub almu'tabarah, maka penetapan fatwa dilakukan melalui pendekatan manhaji, yakni dengan menggunakan al-jam'u wa al-tawfiqi, tarjihi, ilhaqi dan istinbāți.49

Disamping metode-metode tersebut, penetapan fatwa memperhatikan kemaslahatan umum (mașlahah 'ammah). Sebab, fatwa lahir selain didasarkan atas nușūs al-shari'iyyah, juga didasarkan atas refleksi dari kondisi sosial yang melingkupi. Menurut Ma'ruf Amin, fatwa tentang ekonomi syari'ah yang ditetapkan oleh DSN-MUI selain dibangun di atas manhaj tertentu juga tidak terlepas dari landasan umum hukum syari'ah, utamanya mengenai mașlaḥah.

\footnotetext{
${ }^{49}$ Surat Keputusan Dewan Pimpinan Majelis Ulama Indonesia Nomor: U-596/MUI/X/1997 tentang Pedoman Penetapan Fatwa Majelis Ulama Indonesia.
} 
Artinya, aktivitas ekonomi syari'ah harus dilakukan atas dasar pertimbangan mendatangkan manfaat dan menghindarkan madharat (jalb al-mashalih wa dar'u al-mafasid). ${ }^{50}$

Kebutuhan fatwa yang didasarkan atas kemaslahatan (mașlahah) ini menjadi sangat urgen mengingat beberapa faktor: pertama, perubahan sosial, yang meliputi perubahan budaya, ekonomi dan politik masa kini mengharuskan para ahli hukum Islam melakukan telaah terhadap pendapat-pendapat ulama terdahulu yang tidak sesuai dengan konteks sosial saat ini. Kedua, tuntutan perkembangan zaman mengharuskan para ahli hukum Islam kontemporer untuk melihat kompleksitas masalah kontemporer dan memilih pandangan-pandangan dan fatwa hukum yang lebih memudahkan (taysir) dan menghindari kesulitan (al-haraj) dalam hukum-hukum furü'. Ketiga, munculnya kasus-kasus baru dan yang terbarukan mengharuskan adanya ijtihād baru dengan mempertimbangkan aspek mașlaḥah karena masalah-masalah tersebut belum pernah dijawab oleh para fuqah $\bar{a}^{\prime}$ klasik.

Dalam realitasnya, Dewan Syari'ah Nasional Majelis Ulama Indonesia (DSNMUI) dalam berbagai fatwanya sering mendasarkan pada aspek mașlaḥh ini. Fatwa-fatwa tersebut antara lain: Pertama, Fatwa Dewan Syari'ah Nasional No. 16/DSN-MUI/IX/2000 tentang Diskon dalam Murabahah, Kedua, Fatwa Dewan Syari'ah Nasional No. 38/DSN-MUI/X/2002 tentang Sertifikat Investasi Mudharabah Antarbank (Sertifikat IMA). Ketiga, Fatwa Dewan Syariah Nasional No. 50/DSN-MUI/III/2006 tentang Akad Mudharabah Musytarakah. Keempat, Fatwa Dewan Syari'ah Nasional No. 84/DSN-MUI/XII/2012 tentang Metode Pengakuan Keuntungan al-Tamwil bi al-Murabahah (Pembiayaan Murabahah) di Lembaga Keuangan Syari'ah. Kelima, Fatwa Dewan Syari'ah Nasional No. 90/DSN-MUI/XII/2013 tentang Pengalihan Pembiayaan Murabahah Antar Lembaga Keuangan Syari'ah (LKS), dan tentu masih banyak fatwa lain yang mendasarkan diri pada mașlahah mursalah. Hal ini disebabkan karena dalam al-Qur'an dan al-Sunnah tidak banyak membahas secara detail mengenai persoalan ekonomi dan keuangan, namun hanya secara global saja. Sementara itu perkembangan global menuntut adanya respons yang cepat dan efektif dari ajaran Islam terutama terkait dengan ekonomi dan keuangan tersebut.

\footnotetext{
50Ma'ruf Amin, "Menuju Pembaharuan Hukum Ekonomi dan Keuangan Syari'ah" dalam Jurnal Ilmu dan Kebudayaan ULUMUL QUR'AN No. 02/XXI/2012 h. 16.
} 
Dengan demikian dapat dipahami bahwa al-mașlahah sebagai inti maqāșid al-sharīah (tujuan-tujuan syari'ah) dapat digunakan sebagai dalil penetapan hukum khususnya berkenaan dengan berbagai persoalan kontemporer, khususnya yang berkaitan dengan keuangan dan ekonomi syari'ah. Ijtihād dalam ekonomi syari'ah dengan menggunakan al-mașlaḥah dapat dilakukan dengan memenuhi syarat tertentu yakni tidak bertentangan dengan al-Qur'an dan tidak bertentangan dengan al-Hadis serta tidak bertentangan dengan qiyās. Disamping itu tidak bertentangan dengan kemaslahatan yang lebih tinggi, baik dalam cara mewujudkannya maupun dalam cara mempertahankan dari kemusnahannya. Pada prinsipnya, ijtihād di bidang ekonomi syari'ah dapat diimplementasikan dengan menganalisa realitas sosial dan politik dan prioritas dalam mencapai kemaslahatan masyarakat dan negara.

\section{Kesimpulan}

Berdasarkan uraian di atas, dapat disimpulkan bahwa metode istinbāt hukum yang digagas oleh Imam Malik yang ikuti oleh para pengikutnya masih sangat relevan untuk merespons perkembangan hukum Islam pada umumnya, terutama yang terkait dengan perkembangan ekonomi syari'ah. Meskipun metode ini digagas ratusan tahun yang, namun sampai sekarang masih memiliki signifikansi untuk didiskusikan. Sebab, muara mașlaḥah mursalah ini adalah adalah kemaslahatan umat yang memiliki relevansi dengan maqāșid alsharīah. Sesuatu hal yang ditetapkan didasarkan atas kemaslahatan yang mana al-Qur'an dan al-Sunnah tidak pernah melarangnya, maka hal ini menjadi sebuah kebutuhan. Dari penjelasan di atas setidaknya dapat diambil dua kesimpulan.

Pertama, banyaknya persoalan baru yang muncul dalam dunia global ini, yang secara tekstual tidak ditemukan dalilnya di dalam al-Qur'an dan alSunnah., ijma' dan qiyās, bahkan dalam kitab-kitab fiqh yang ditulis para fuqaha pada masa lalu, membuat ahli hukum Islam masa kini melakukan ijtihād. salah satu metode ijtihōd yang banyak dipergunakan para ahli hukum Islam kontemporer untuk menemukan hukum Islam adalah al-Mașlahah atau mașlahah mursalah. Sedikitnya naș-naș yang menyinggung masalah yang terkait dengan kebijakan-kebijakan ekonomi teknis, membuka peluang yang besar untuk mengembangkan ijtihäd dengan prinsip mașlaḥah. Al-mașlaḥah 
sebagai salah satu model pendekatan dalam ijtihād menjadi sangat vital dalam pengembangan ekonomi Islam dan siyāsah iqtișādiyiah (kebijakan ekonomi).

Kedua, dalam merespons permasalahan ekonomi syari'ah yang berkembang, fatwa memiliki peran penting dalam mendasari perkembangan tersebut. Dalam merespons perkembangan ekonomi syari'ah ini, melalui fatwanya, DSN-MUI melakukan ijtihād jamā'i yang dalam proses penetapannya menggunakan tiga pendekatan, yaitu pendekatan naș qat'y, pendekatan qawly dan pendekatan manhaji. Disamping metode-metode tersebut, penetapan fatwa memperhatikan kemaslahatan umum (mașlahah 'ammah) yang dalam istilah hukum Islam dikenal dengan mașlahah mursalah.

Kebutuhan fatwa yang didasarkan atas mașlahah mursalah ini menjadi sangat urgen. Hal ini disebabkan karena mengingat beberapa faktor, yaitu; perubahan sosial yang meliputi perubahan budaya, ekonomi dan politik mengharuskan para ahli hukum Islam melakukan telaah terhadap pendapatpendapat ulama terdahulu yang tidak sesuai dengan konteks sosial saat ini; tuntutan perkembangan zaman mengharuskan para ahli hukum Islam melihat kompleksitas masalah kontemporer dan memilih pandangan yang lebih memudahkan (taysir) dan menghindari kesulitan (al-haraj); dan munculnya kasus-kasus baru mengharuskan adanya ijtihād dengan mempertimbangkan aspek mașlahah mursalah ini.

Implementasi metode mașlahah mursalah ini dapat dilihat dari beberapa produk fatwa DSN-MUI, antara lain: Pertama, Fatwa Dewan Syari'ah Nasional No. 16/DSN-MUI/IX/2000 tentang Diskon dalam Murabahah. Kedua, Fatwa Dewan Syari'ah Nasional No. 38/DSN-MUI/X/2002 tentang Sertifikat Investasi Mudharabah Antarbank (Sertifikat IMA). Ketiga, Fatwa Dewan Syari'ah Nasional No. 50/DSN-MUI/III/2006 tentang Akad Mudharabah Musytarakah. Keempat, Fatwa Dewan Syari'ah Nasional No. 84/DSN-MUI/XII/2012 tentang Metode Pengakuan Keuntungan al-Tamwil bi al-Murabahah (Pembiayaan Murabahah) di Lembaga Keuangan Syari'ah. Kelima, Fatwa Dewan Syari'ah Nasional Nomor: 90/DSN-MUI/XII/2013 tentang Pengalihan Pembiayaan Murabahah Antar Lembaga Keuangan Syari'ah (LKS), dan tentu masih banyak fatwa lain yang mendasarkan diri pada mașlahah mursalah ini.

Dengan demikian dapat dipahami bahwa dalam merespons berbagai problematika yang terkait keuangan syari'ah dibutuhkan fatwa yang di- 
dasarkan atas ijtihād yang salah satu metodenya adalah mașlaḥah mursalah yang mana mentode istinbatnya dengan mempertimbangkan aspek kemaslahatan. Bahkan metode mașlahah ini menjadi penting mengingat banyak persoalan ekonomi syari'ah yang harus segera dijawab dengan fatwa, namun secara tekstual tidak tercantum dalam al-Qur'an, al-Sunnah, bahkan tidak terdapat pula dalam kitab-kitab kuning yang merupakan hasil kreasi ijtihād para ulama terdahulu. Oleh sebab, dalam menjawab persoalan tersebut sangat urgen untuk merujuk pada metode mașlahah mursalah yang dikenal juga dengan istilah metode istișlah. [a]

\section{DAFTAR PUSTAKA}

Abdurrahman, Jalaluddin, al-Mașālih al-Mursalah wa Makānatuhā fi al-Tashri', t.p: Mathba'ah al-Sa'adah, 1983.

Abu Zahrah, Muhammad, Ushul Fiqh, Beirut: Dar al-Fikr al-Araby, t.th.

Agustianto, "Urgensi Mașlahah dalam Ijtihad Ekonomi Islam" dalam http://www.agustiantocentre.com/?p=424 diunduh pada hari Selasa, 28 Maret 2017

Ahmad bin Faris bin Zakariyya, Mu'jam Maqāyis al-Lugah, Juz III, Beirut: Dar alFikr, 1979.

Amin, Ma'ruf, "Menuju Pembaharuan Hukum Ekonomi dan Keuangan Syari'ah" dalam Jurnal Ilmu dan Kebudayaan Ulumul Qur'an No. 02/XXI/2012.

Amir Syarifuddin, Ushul Fiqh, vol. 2, Cet. V, Jakarta: Kencana, 2009.

Asmawi, "Konseptualisasi Teori Mașlahah" dalam Salam: Jurnal Sosial dan Budaya Syar'i, Fakultas Syari'ah dan Hukum UIN Syarif Hidayatullah Jakarta, Vol. 1, No. 2, 2014.

al-Bajqani, Muhammad Abdul Ghani, al-Madkhal ilā Ușūl al-Fiqh al-Maliki. Beirut: Dar Libnan li al-Tiba'ah wa al-Nasyr.

Baqiy, Muhammad Fuad 'Abdul, Muwatța' Imām Mālik, Beirut: Dar al-Fikr, juz I, $1405 \mathrm{H}$.

Bustaman Ahmad, Kamaruzzaman, Islam Historis; Dinamika Studi Islam di Indonesia, Yogyakarta: Galang Press, 2002.

Dutton, Yasin, The Origins of Islamic Law: The Quran, The Muwatta', and Madinan 'Amal, Cet. I, Richmond Survey: Curzon Press, 1999. 
Effendi M. Zein, Satria, Ushul Fiqh, Jakarta: Kencana, 2005.

al-Ghazali, Abu Hamid Muhammad Ibn Muhammad, al-Mustasfā min 'Ilm alUșūl, Beirut: Dār al-Kutub al 'Ilmiyyah, 1993.

Hasan, M Ali, Perbandingan Madzhab Fiqh, Jakarta: RajaGrafindo Persada, 1997.

Hosen, M. Nadratuzzaman dkk, Materi Dakwah Ekonomi Syari'ah, Jakarta: PKES (Pusat Komunikasi Ekonomi Syari'ah), t.th.

Ibn Anas, Imam Malik, al-Muwatta', diriwayatkan oleh Yahya ibn Yahya alLaitsy, Damaskus: Muassasah Risalah Nasyirun, 2013.

Ibn Manzur, Muhammad bin Mukrim, Lisān al-'Arab, Juz II, Beirut: Dar Sadir, $1414 \mathrm{H}$.

Ismatullah, Dedi, Sejarah Sosial Hukum Islam, Bandung: Pustaka Setia, 2011.

Juandi, "Aspek Sosio-Politik dalam Konstruksi Hukum Imam Malik Bin Anas" dalam Jurnal Istinbath Vol. 9, Nomor 1, Edisi Mei 2012.

al-Juzairi, Abdurrahman, Kitāb al-Fiqh 'alā Madhāhib al-Arba'ah, Beirut: Dar alFikr, 2004.

Khalil, Rasyad Hasan, Tārikh al-Tashri' al-Islāmy, terj. Nadirsyah Hawari, Jakarta: Amzah, 2009.

al-Khind, Mustafa Sa'id, Athār al-Ikhtilāf fi Qawā'id al-Ușūliyyah fi Ikhtilāf alFuqahō', Beirut: Muassasah al-Risalah, 1981.

Ma'shum Zein, Muhammad, Arus Pemikiran Empat Madzhab; Studi Analisis Istinbath Para Fuqaha, Jombang: Darul Hikmah, 2008.

Phipips, Abu Ameenah Bilal, The Evolution of Fiqh Islamic Law and The Madhhabs, cet. 2, Kuala Lumpur: A.S. Noordeen, 1411H./1990M.

Pusat Pengkajian dan Pengembangan Ekonomi Islam (P3EI), Ekonomi Islam, Jakarta: Rajawali Pers, 2012.

al-Razi, Abu 'Abdillah Zain al-Din Muhammad bin Abu Bakr, Mukhtar al-Sihah, Beirut: al-Maktabah al-Asriyyah, 1999.

Rahman, Fazlur, Membuka Pintu Ijtihad, terjemah Anas Mahyuddin, Bandung: Pustaka, 1984.

Rahman, Fazlur, Membuka Pintu Ijtihad, terjemahan Anas Mahyuddin, Bandung: Pustaka, 1984.

Ramli, SA, Muqaranah Madhāhib fi ' I-Ușūl, Jakarta: Gaya Media Pratama, 1999.

Rofiq, Ahmad, Hukum Islam di Indonesia, Jakarta: PT Raja Grafindo Persada, 2003.

80 || Volume 27, Nomor 1, April 2017 
Sakirman, “Urgensi Mașlahah dalam Konsep Ekonomi Syari'ah" dalam PALITA: Journal of Social-Religi Research, , Vol.1, No.1, April 2016.

Setiyanto, Danu Aris, "Pemikiran Hukum Islam Imam Malik bin Anas: Pendekatan Sejarah Sosial" dalam Al-Ahkam: Jurnal Ilmu Syari'ah dan Hukum, Fakultas Syari'ah IAIN Surakarta, Vol. 1, No. 2, 2016.

Soejoeti, Zarkowi, Pengantar Ilmu Fiqh, Semarang: Walisongo Press, 1987.

Supriyadi, Dedi, Sejarah Hukum Islam; Dari Kawasan Jazirah Arab Sampai Indonesia, Bandung: Pustaka Setia, 2007.

Surat Keputusan Dewan Pimpinan Majelis Ulama Indonesia Nomor: U596/MUI/X/1997 tentang Pedoman Penetapan Fatwa Majelis Ulama Indonesia.

Syahab, Said Abdullah, "Al-Mașlahah dan Ijtihad dalam Ekonomi Islam" dalam Jurnal TAJDID Vol. XII, No. 2, Juli-Desember 2013.

al-Syatibi, Abi Ishaq, Al-Muwafaqat fi Ushul al-Syari'ah, Beirut: Dar al-Ma'rifat, 2004.

Syarifuddin, Amir, Ushul Fiqh, vol. 2, cet. 5, Jakarta: Kencana, 2009.

Wahab, Khallaf Abdul, Ilmu Ushul al-Fiqh, terjemahan Muh Zuhri dan Ahmad Qorib, Semarang: Toha Putra, 1994.

Zahrah, Muhammad Abu, Malik; Hayatuhu wa 'Ushruhu wa 'Ara'uhu wa Fiqhuhu, Mesir: Dar al-FIkri al-'Arabi, t.th.

Zahrah' Muhammad Abu, Ușūl al-Fiqh, Mesir: Dar al-'Arabi, 1958.

Zaidan, Abd al-Karim, al-Wajīz fi Ușūl al-Fiqh, Baghdad: Dar al-Arabiah alTiba'ah, 1971.

al-Zuhaily, Wahbah, al-Fiqh al-Islämy wa Adillatuhu, Damaskus: Dar al-Fikr, 1997. 
82 || Volume 27, Nomor 1, April 2017 